\title{
Redescription and synonymy of Stenaelurillus arambagensis (Biswas et Biswas, 1992) comb.n. (Araneae: Salticidae)
}

\author{
Переописание и синонимия Stenaelurillus arambagensis \\ (Biswas et Biswas, 1992) comb.n. (Araneae: Salticidae)
}

\author{
John T.D. Caleb ${ }^{1, *}$, Dhruv A. Prajapati ${ }^{2,5}$, \\ Nayan Rameshwar Maheshwari ${ }^{3}$, Rajesh V. Sanap ${ }^{4}$ \\ Азж.Т.А. Калеб, А.А. Праджапати, \\ Н. Рамешвар Махешвари, Р.В. Санап
}

\footnotetext{
${ }^{1}$ Zoological Survey of India, Prani Vigyan Bhawan, M-Block, New Alipore, Kolkata-700 053, West Bengal, India. Email: caleb87woodgate@gmail.com

${ }^{2}$ Division of Arachnology, Department of Zoology, Sacred Heart College, Thevara, Cochin-682 013, Kerala, India.

${ }^{3}$ Department of Zoology, Moolji Jaitha College, Jalgaon-425 001, Maharashtra. India.

${ }^{4}$ National Centre for Biological Sciences, Tata Institute of Fundamental Research, Bangalore-560 065, Karnataka, India.

${ }^{5}$ Research and Development Centre, Bharathiar University, Coimbatore-641 014, India.

${ }^{*}$ Corresponding author.
}

KEY WORDS: Distribution, Stenaelurillus, Salticidae, India, synonymy. КЛЮЧЕВЫЕ СЛОВА: Распространение, Stenaelurillus, Salticidae, Индия, синонимия.

ABSTRACT. Marpissa arambagensis Biswas et Biswas, 1992 is transferred to the genus Stenaelurillus Simon, 1886: $S$. arambagensis (Biswas et Biswas, 1992) comb.n. The species is redescribed and illustrated, its refined distribution is mapped. Stenaelurillus digitus Prajapati, Murthappa, Sankaran et Sebastian, 2016 is synonymized with $S$. arambagensis.

PЕЗЮMЕ. Marpissa arambagensis Biswas et Biswas, 1992 переведена в род Stenaelurillus Simon, 1886: S. arambagensis (Biswas et Biswas, 1992) comb.n. Вид переописан и иллюстрирован, его уточненное распространение прокартировано. Stenaelurillus digitus Prajapati, Murthappa, Sankaran et Sebastian, 2016 синонимизирован с $S$. arambagensis.

\section{Introduction}

The genus Stenaelurillus was established by Simon in 1886 . The genus presently consists of 39 valid species described from Africa and Asia [WSC, 2017], of which seven species are known from India: $S$. lesserti Reimoser, 1934; S. sarojinae Caleb et Mathai, 2014; $S$. albus Sebastian, Sankaran, Malamel et Joseph, 2015; S. jagannathae Das, Malik et Vidhel, 2015; S. metallicus Caleb et Mathai, 2016; S. digitus Prajapati, Murthappa, Sankaran et Sebastian, 2016; and S. gabrieli Prajapati, Murthappa, Sankaran et Sebastian, 2016. While re-examining old salticid types retained at the National Zoological Collection, Zoological Survey of India, Kolkata and the freshly collected material from Peda
Cherlopalle, Andhra Pradesh, we have found out that the species Marpissa arambagensis Biswas et Biswas, 1992 was misplaced and is to be transferred to the genus Stenaelurillus Simon, 1886. In this paper, we have established a new combination for the latter species name - Stenaelurillus arambagensis (Biswas et Biswas, 1992) comb.n. - and have redescribed and illustrated this species based on the type and newly collected material. A refined distributional map is provided as well. The name $S$. digitus is hereby recognized as a junior synonym of $S$. arambagensis.

\section{Materials and methods}

The specimens were hand collected and preserved in $70 \%$ ethanol. Images of the type specimens were made by means of a Leica EZ4 HD stereomicroscope equipped with LAS EZ software. The epigyne was dissected and cleared in $10 \% \mathrm{KOH}$. All measurements are in $\mathrm{mm}$. The studied specimens have been deposited in the National Zoological Collection, Zoological Survey of India, Kolkata (ZSI), Division of Arachnology, Department of Zoology, Sacred Heart College, Thevara, Cochin, Kerala (ADSH) and the Western Regional Centre, Zoological Survey of India (ZSI-WRC), Pune. Abbreviations used: AEW - anterior eyes width, a.s.l. - above sea level, D described, EFL - eye field length, PEW - posterior eyes width, RTA - retrolateral tibial apophysis, VTA - ventral tibial apophysis. 

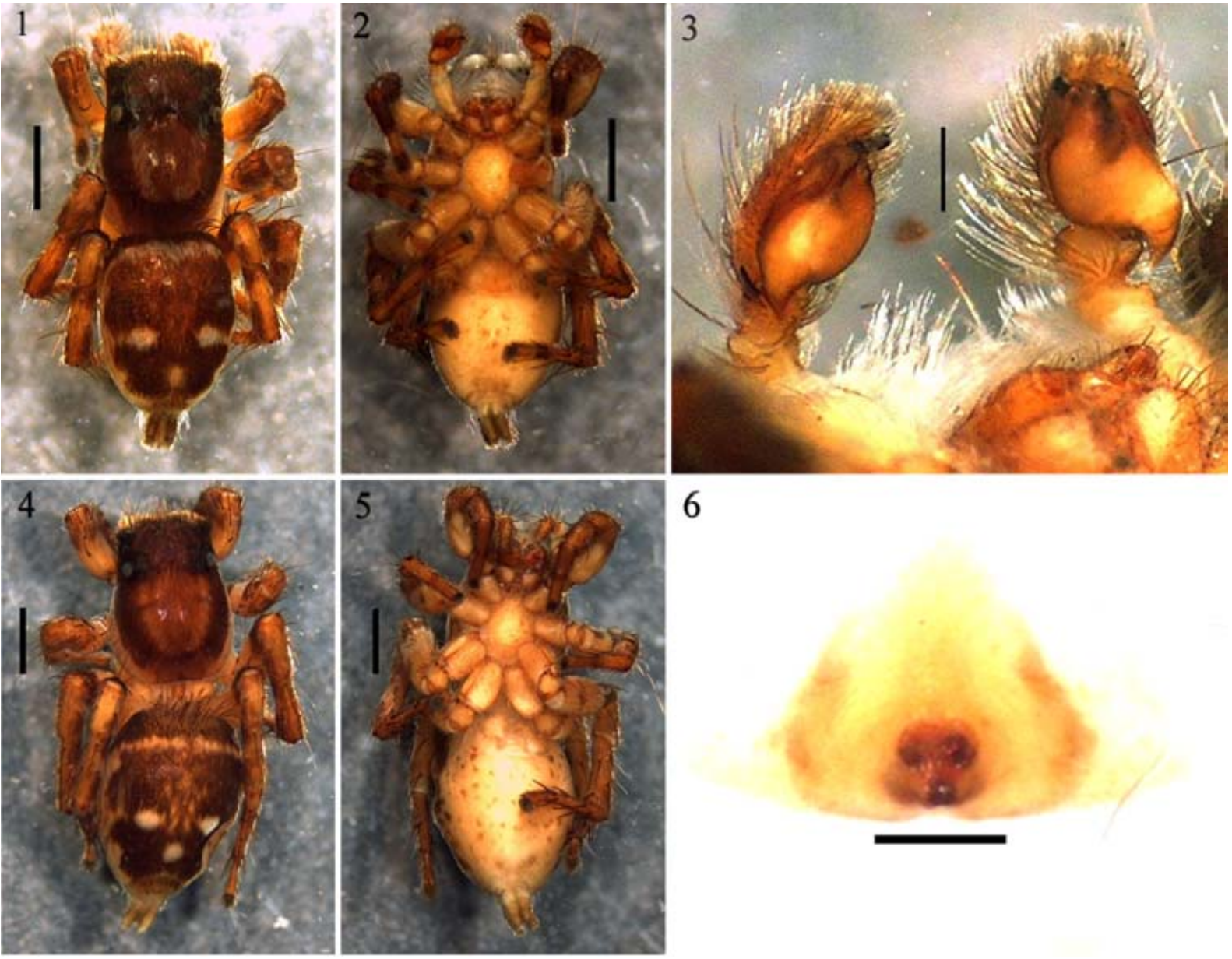

6

Figs 1-6. General appearance and copulatory organs of S. arambagensis comb.n.: $0^{7}$ allotype (ZSI 5384/18) (1-3) and 9 holotype (ZSI 5376/18) (4-6): 1 - male, dorsal view; 2 - ditto, ventral view; 3 - right palp, retrolateral, left palp, ventral view; 4 - female, dorsal view; 5 - ditto, ventral view; 6 - epigyne, ventral view. Scale bars: (1-2, 3-4) $1 \mathrm{~mm}$; (3) $0.25 \mathrm{~mm}$.

Рис. 1-6. Общий вид и копулятивные органы S. arambagensis comb.n.: аллотип О7 (ZSI 5384/18) (1-3) и голотип + (ZSI 5376/ 18) (4-6): 1 - самец, вид сверху; 2 - то же, вид снизу; 3 - правая пальпа, ретролатерально, левай пальпа вентрально; 4 - самка, вид сверху; 5 - то же, вид снизу; 6 - эпигина, вид снизу. Масштаб: (1-2, 3-4) 1 мм; (3) 0,25 мм.

\section{Taxonomy}

Stenaelurillus arambagensis (Biswas et Biswas, 1992), comb.n.

Figs 1-17, Map.

Marpissa arambagensis Biswas et Biswas, 1992: 390, figs 20 22 (D) ).The type series is kept at the ZSI; examined.

Stenaelurillus digitus Prajapati, Murthappa, Sankaran et Sebastian, 2016: 327, figs 1C-D, 6A-D, 7A-E, 8A-C, 9A-D (D $0^{3}+$ ), Syn.n. The type series is kept at the ADSH; examined.

TYPES. Marpissa aramabagensis Biswas et Biswas, 1992: holotype + (ZSI-5376/18) and allotype $\sigma^{7}$ (ZSI-5384/18) from Chandur forest $\left(22.91^{\circ} \mathrm{N}, 87.76^{\circ} \mathrm{E}\right), 26 \mathrm{~m}$ a.s.1., Arambagh, Hugli District, West Bengal, India, 26.02.1986, Bijan Biswas. - Stenaelurillus digitus Prajapati, Murthappa, Sankaran et Sebastian, 2016: holotype $O^{7}\left(\mathrm{ADSH}\right.$ 83503Di) and paratypes $2 \mathrm{O}^{7} \mathrm{O}^{7}, 3$ 우 (ADSH 83503Dii) from Vijaynagar $\left(23.998956^{\circ} \mathrm{N}, 73.280219^{\circ} \mathrm{E}\right), 307 \mathrm{~m}$ a.s.l., Gujarat, India, 27.06.2014, Prajapati.

OTHER MATERIAL. INDIA: $10^{7}$ (ZSI-AA579), 1 (ZSIAA578), Peda Cherlopalle $\left(15.278153^{\circ} \mathrm{N}, 79.571527^{\circ} \mathrm{E}\right), 90 \mathrm{~m}$ a.s.1., Kanigiri, Andhra Pradesh, 04.12.2016, John Caleb \& Job Daniel; $10 \bigcirc^{7} \sigma^{7}, 5$ 우 (the first author's personal collection),
4.12.2016, John Caleb \& Job Daniel; $2 \sigma^{7} \sigma^{7}, 2$ 우 (ZSI-WRC. Lot No. 106, Reg. No. Ar/586), Jalgaon $\left(20.975505^{\circ} \mathrm{N}, 75.565434^{\circ}\right.$ E), 193 m a.s.1., Maharashtra, 30.09.2015, Nayan R. Maheshwari.

DIAGNOSIS. $S$. arambagenesis can be easily distinguished from other Stenaelurilus species by the following characters: the long, thick, finger-like apophysis of the embolar division (called the embolus in the original description of $S$. digitus), directed at 11 o'clock position; the short, thick embolus (Figs 3, 8, 14); the massive ventral tibial apophysis (Figs 7, 15); the epigyne with closely placed copulatory openings on a sclerotized plate and with a raised posterior region having the $\mathrm{W}$-shaped margin (Figs 6, 10, 16); the insemination ducts simple, short and linear (Fig. 12); the spermathecae spherical, contiguous (Figs 11, 17) (see also Prajapati et al. [2016: sub. S. digitus]).

REMARKS. Biswas, Biswas [1992] described Marpissa arambagensis from the Chandur forest in West Bengal on the basis of the female holotype. The original paper also referred to the male allotype, which was neither described, nor illustrated. The species, 


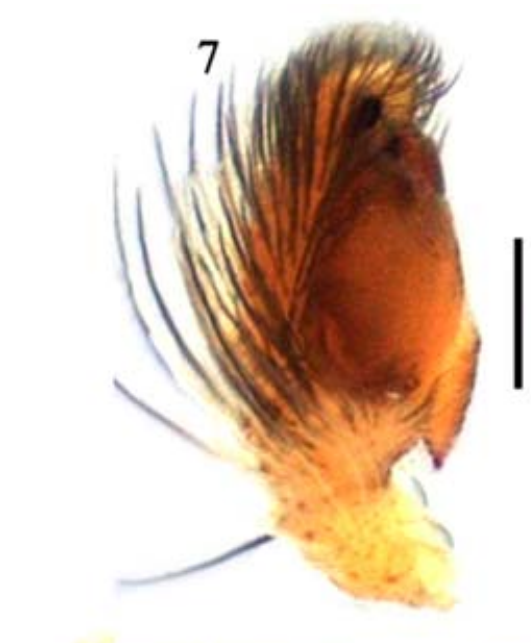

10

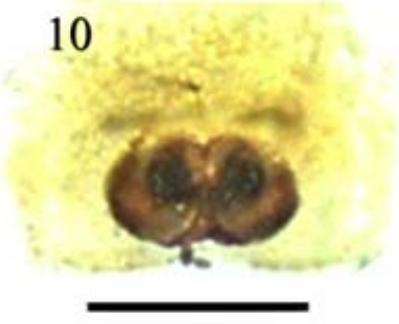

11

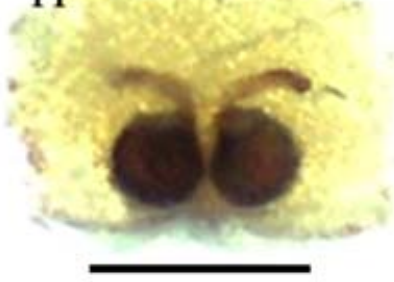

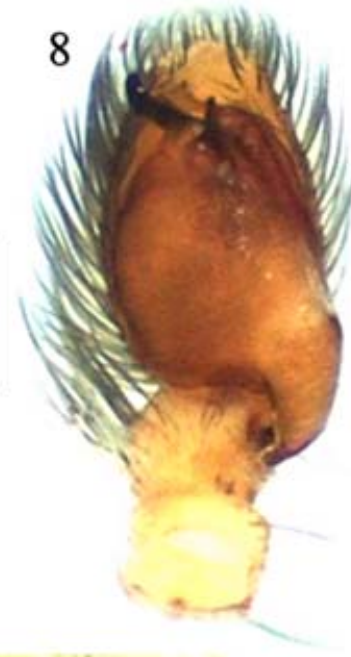

12

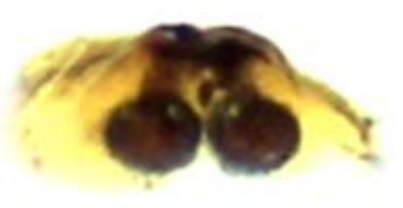

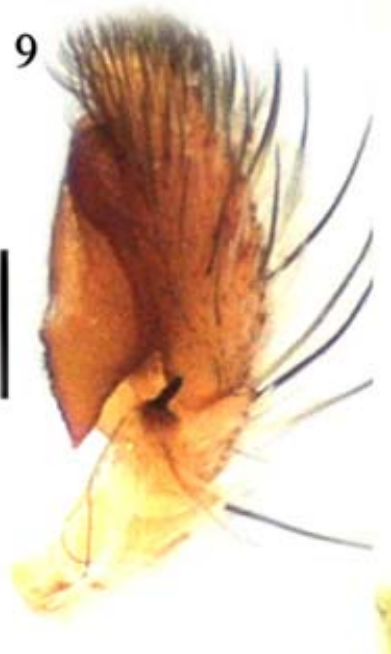

13

Figs 7-13. Copulatory organs of $S$. arambagensis comb.n. (specimens from Andhra Pradesh): 7 - left male palp, prolateral view; 8 ditto, ventral view; 9 - ditto, retrolateral view; 10 - epigyne, ventral view; 11 - vulva, dorsal view; 12 - ditto, posterior view; 13 ditto, lateral view. Scale bars: (6-11) $0.25 \mathrm{~mm}$.

Рис. 7-13. Копулятивные органы S. arambagensis comb.n. (экземпляры из Андхра Прадеш): 7 - левая пальпа самца, пролатерально; 8 - то же, вентрально; 9 - то же, сзади-латерально; 10 - эпигина, вентрально; 11 - вульва, дорзально; 12 - то же, вид сзади; 13 - то же, вид сбоку. Масштаб: (6-11) 0,25 мм.

however, was clearly misplaced. The characters such as the unidentate chelicerae, carapace with a pair of white longitudinal stripes, the anterior region of abdomen with thick, long brown hairs, the abdomen pattern with a transverse white band and three white spots (cf. Fig. 4 with fig. 20 in Biswas \& Biswas [1992]), a pair of spherical spermathecae, the male palp with the large posterior tegular apophysis are evidence that the species is to be placed in Stenaelurillus.

JUSTIFICATION OF SYNONYMY. S. digitus was recently described from Gujarat, India. The authors failed to compare their species with $S$. aramabagensis, because it was originally described in Marpissa. Yet, the original description and published illustrations were not adequate for recognizing the species. An examination of freshly collected material from Peda Cherlopalle (Andhra Pradesh), Jalgaon (Maharashtra) and a re-examination of the type series of Marpissa arambagensis have revealed that $S$. digitus is identical to $S$. aramabagensis by the conformation of its copulatory organs (cf. Figs 3, 6, 7-13 with figs $7 \mathrm{C}-\mathrm{E}, 8 \mathrm{~A}-\mathrm{C}$ in Prajapati et al. [2016]), suggesting that the former name is a junior synonym of the latter.

Another similar species - Stenaelurillus jagannathae Das Malik et Vidhel, 2015 — could also be a junior synonym of $S$. arambagensis because of the similar palpal conformation showing the strikingly similar structure of the thick apophysis in the embolar division accompanied by the short embolus. The variations seen in the palp of $S$. jagannathae, as reported by Prajapati et al. [2016], could be attributed to a slight clockwise rotation of the bulbus, resulting in the positional change of the embolus from 12 o'clock to 1 o'clock (see figs 3-6 in Vidhel et al. [2015]). The epigyne with the closely placed copulatory openings, the short insemination ducts and the closely placed spherical spermathecae (see figs 7-8 in Vidhel et al. [2015]) also point to the possible synonymy of both species names. However, the formal synonymy is postponed until the type series of $S$. jagannathae has been re-examined.

DESCRIPTION. FEMALE (holotype, ZSI-5376/ 18, Figs 4-6, 16-17): Total length 5.53, carapace 2.51 long, 1.90 wide; abdomen 3.02 long, 2.13 wide. AEW 1.46, PEW 1.41, EFL 0.76. Carapace reddish brown, with a pair of longitudinal stripes on the thoracic region; lateral margins of carapace covered with broad patches of white hairs (Fig. 4). Clypeus covered with white hairs. Chelicerae brownish, unidentate. Endites, labium and sternum yellowish (Fig. 5). Legs yellowish, 


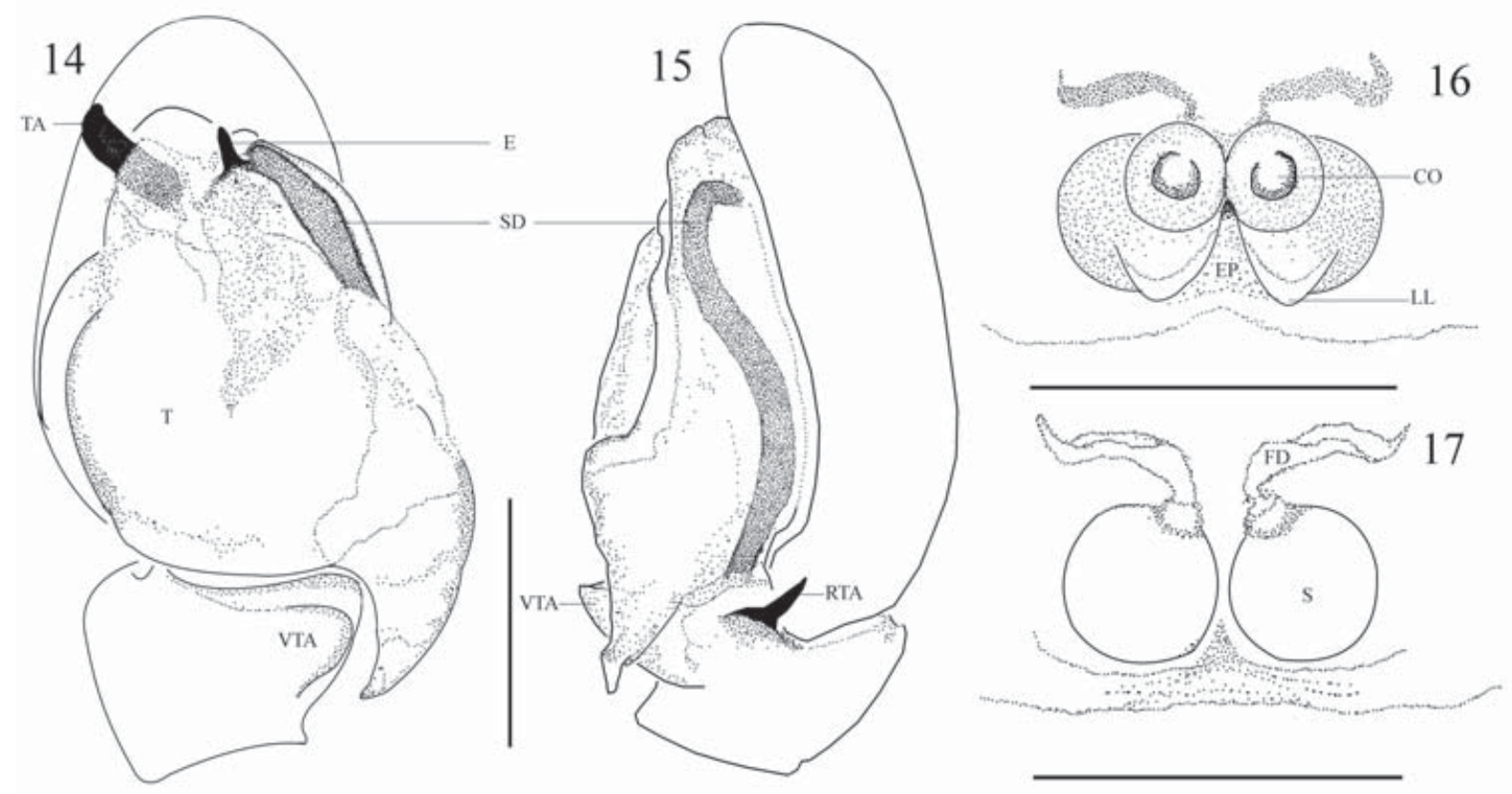

Figs 14-17. Stenaelurillus arambagensis comb.n.: 14 - left male palp, ventral view; 15 - ditto, retrolateral view; 12 - epigyne, ventral view; 13 - vulva, dorsal view. Scale bars: (10-13) $0.25 \mathrm{~mm}$. Abbreviations: CO — copulatory opening; E — embolus; EP epigynal pocket; FD - fertilization duct; LL — lateral lobe; RTA — retrolateral tibial apophysis; S — spermathecae; SD — sperm duct; T - tegulum; TA — apophysis of the embolic division; VTA — ventral tibial apophysis.

Рис. 14-17. Stenaelurillus arambagensis comb.n.: 14 - левая пальпа самца, вентрально; 15 - тоже, ретролатерально; 12 эпигина, вид снизу; 13 - вульва, вид сверху. Масштаб: (10-13) 0,25 мм. Сокращения: СО - копулятивное отверстие; Е эмболюс; ЕР - эпигинальный карман; FD - оплодотворительный канал; LL — боковая доля; RTA — боковой тибильный отросток; S - сперматеки; SD - семенной каналец; T - тегулум; TA — апофиза эмболярного отдела; VTA — вентральный тибиальный отросток.

with dark brown patches. Abdomen reddish brown, outlined by a stripe of white hairs anteriorly and a broad patch of pale yellow hairs; a row of smaller spots converging between a pair of large white spots, another slightly smaller spot presents further down; pale yellow chevron-shaped markings present at the posterior region (Fig. 5). Spinnerets yellowish. Epigynal plate sclerotized, with the raised posterior region; small and broad epigynal pocket forms W-shaped posterior margin; copulatory openings closely placed; copulatory ducts short and straight; spermathecae spherical (Figs $6,10-13,16,17)$.

MALE (allotype, ZSI-5384/18, Figs 1-3, 14-15): Total length 4.38 , carapace 2.18 long, 1.57 wide; abdomen 2.20 long, 1.63 wide. AEW 1.36, PEW 1.34, EFL 0.75. Coloration pattern as in the female (Figs 12 ). Pedipalps covered with pale yellow hairs; the apophysis of the embolar division thick, almost flattened and long, protruding prolaterally; embolus thick, short and straight (Figs 3, 8, 14); significantly curved proximal retrolateral lobe of the tegulum with a narrow tip (Figs 3, 8 \& 14); VTA large; RTA short, canine toothlike, directed dorsally (Figs. 7, 9, 15).

DISTRIBUTION. India (Andhra Pradesh, Gujarat, Maharashtra, West Bengal) (Map).

ACKNOWLEDGEMENTS. The first author is grateful to Dr Kailash Chandra, Director of the Zoological Survey of
India, Kolkata, for his immense encouragement to carry out the work and permitting the examination of the types. Sincere thanks go to Dr Shelley Acharya (Head, Arachnology Division, ZSI) for her support and to Mr. Chandan who readily loaned the material for this study. D.A. Prajapati thanks Dr P.A. Sebastian for his encouragement and for providing necessary facilities during the present study. Nayan Rameshwar Maheshwari thanks Dr Bhatnagar, Officerin-Charge, and Mr. Patil S. R., Western Regional Centre, ZSI, Pune, for their help and permission to deposit the studied specimens in their collections. We are grateful to Dr Dmitri Logunov (Manchester, UK) for providing valuable suggestions and editing the manuscript.

\section{References}

Biswas B., Biswas K. 1992. Araneae: Spiders // State Fauna Series 3: Fauna of West Bengal. Vol.3. P.357-500.

Caleb T.D.J., Mathai M.T. 2014. Description of some interesting jumping spiders (Araneae: Salticidae) from South India // Journal of Entomology and Zoology Studies.Vol.2. P.63-71.

Caleb T.D.J., Mathai M.T. 2016. A new jumping spider of the genus Stenaelurillus Simon, 1886 from India (Araneae: Salticidae: Aelurillina) // Zootaxa. Vol.4103. No.2. P.185-188. http://dx.doi.org/10.11646/zootaxa.4103.2.10

Prajapati D.A., Murthappa P.S., Sankaran P.M., Sebastian P.A. 2016. Two new species of Stenaelurillus Simon, 1886 from India (Araneae: Salticidae: Aelurillina) // Zootaxa. Vol.4171. No.2. P.321-334. 


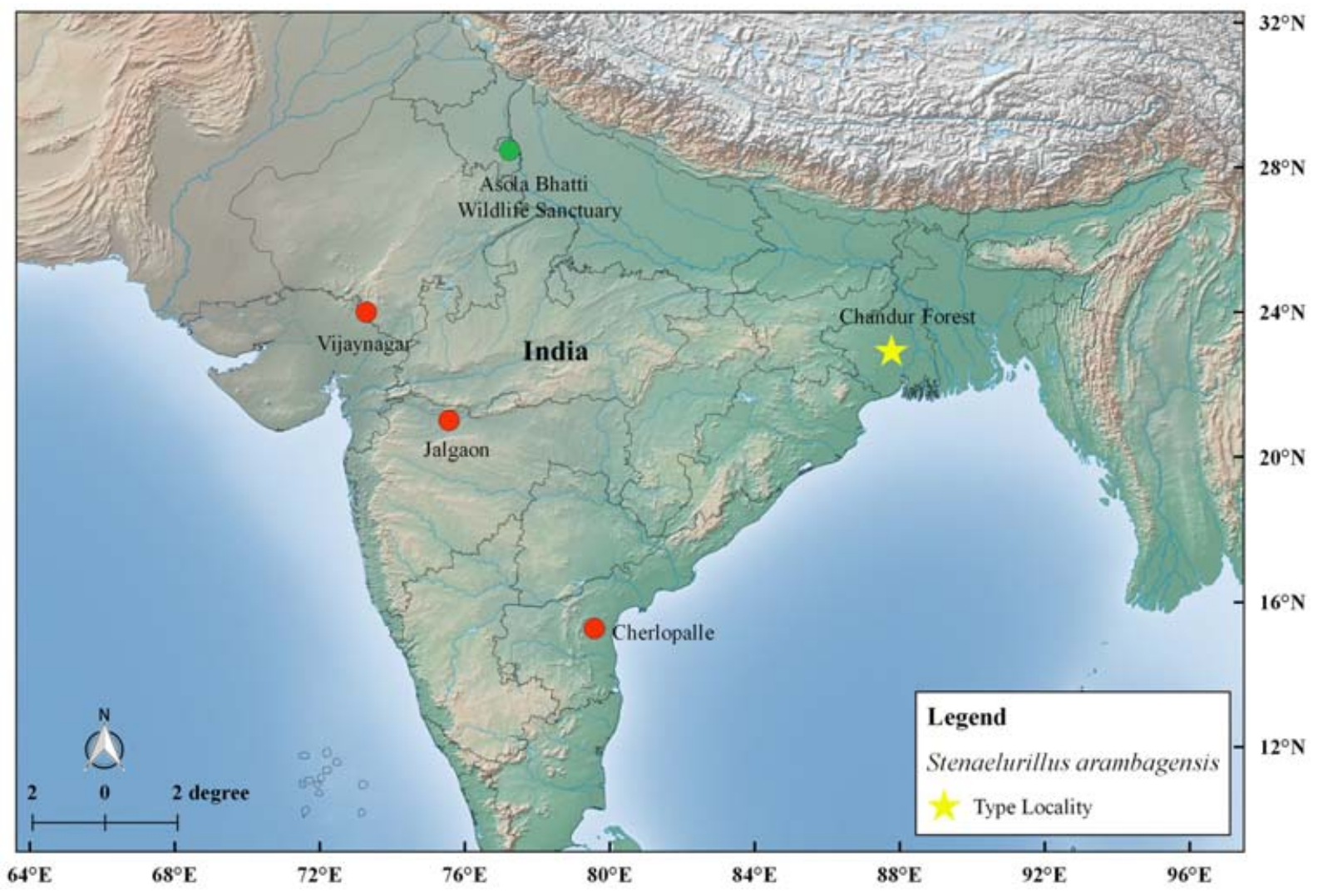

Map. Collecting localities of Stenaelurillus sp. in India.

Карта. Точки сбора Stenaelurillus sp. в Индии.

Reimoser E. 1934. Araneae aus Süd-Indien // Revue Suisse de Zoologie. T.41. S.465-511. http://dx.doi.org/10.5962/ bhl.part. 155628

Sebastian P.A., Sankaran P.M., Malamel J.J., Joseph M.M. 2015. Description of new species of Stenaelurillus Simon, 1886 from the Western Ghats of India with the redescription of Stenaelurillus lesserti Reimoser, 1934 and notes on mating plug in the genus (Arachnida, Araneae, Salticidae) // ZooKeys. Vol.491. P.63-78. http://dx.doi.org/10.3897/zookeys.491.8218

Simon E. 1886. Études arachnologiques. 18e Mémoire. XXVI. Matériaux pour servir à la faune des Arachnides du Sénégal. (Suivi d'une appendice intitulé: Descriptions de plusieurs es- pèces africaines nouvelles) // Annales de la Société Entomologique de France. Vol.6. No.5. P.345-396.

Vidhel B.P., Malik S., Sabata B. C., Das S.K. 2015. A new spider species of the genus Stenaelurillus Simon, 1886 (Araneae: Salticidae: Aelurillinae) from India // International Journal of Science and Research. Vol.4. No.7. P.2332-2336.

WSC 2017. World Spider Catalog. Natural History Museum Bern; online at: http://wsc.nmbe.ch, version 18 (accessed on $21 \mathrm{st}$ March 2017). 